ARTICLE

https://doi.org/10.1057/s41599-019-0386-7

\title{
Rehumanizing the migrant: the translated past as a resource for refashioning the contemporary discourse of the (radical) left
}

\author{
Mona Baker (1) ${ }^{1 \star}$
}

\begin{abstract}
This study examines conceptions of outsiders to the polity, focusing on the lexical items migrant(s), refugee(s), and exile(s) in both internet- and print-based sources. Drawing primarily on a subsection of the Genealogies Internet Corpus consisting of left-wing sources, I argue that left-wing politics is currently caught up in the rhetoric of the right and of mainstream institutions in society, largely reproducing the same discursive patterns even as it sets out to challenge them. Dominant patterns in left-wing Internet sources reveal, for example, that the economic migrant vs. political refugee distinction enforced by mainstream institutions remains largely intact, that the assumption of a "refugee crisis" unfolding in Europe is accepted at face value, and that the left is entangled in the same politics of labeling imposed by the right, reproducing designations such as "undocumented migrants" uncritically. Refugees and migrants, moreover, are represented as victims with no agency, are discussed in legal terms that serve to dehumanize them, and are repeatedly "quantified" as a homogenous and potentially problematic category. Acknowledging the contagious nature of dominant discourses and the difficulty of finding an alternative language with which to argue against established institutional rhetoric, the study further explores historical models that appear more consistent with the values espoused by left-wing politics today. It examines a subcorpus of modern English translations of ancient Greek texts such as Thucydides' The Peloponnesian War and Herodotus's Histories to demonstrate the viability of adopting a different conceptualization of refugees and other outsiders to the polity that may be drawn from classical antiquity-and/or from nineteenth- and early twentieth-century receptions of texts originating in classical antiquity-and the possibility of developing an alternative discourse with which to speak about migrants in the present.
\end{abstract}

\footnotetext{
${ }^{1}$ Centre for Translation \& Intercultural Studies, University of Manchester, Manchester, UK. *email: mona.baker@manchester.ac.uk
} 


\section{Introduction}

$\mathrm{n}$ the Home Office Phrasebook: How to Speak the Dialect of Dehumanization, Patrick Page ${ }^{1}$ suggests that the widely criticized, openly offensive language used by politicians and public leaders to refer to migrants-David Cameron's use of swarm, Donald Trump's infestation, the BBC's flood, the Daily Mail's reference to a tidal wave of migrants-is only the tip of the iceberg. "[B]eneath this intentionally offensive language", he argues, "there lurks an official language, a specific jargon, deployed by government officials in its day to day operation of immigration enforcement". "Like all jargon", he continues, this is "extraordinarily contagious, and so even those who oppose the government's methods of immigration enforcement, and the narrative that underpins it, start to use it themselves. We end up being complicit". This article analyses some aspects of the (radical) left's discourse on migration to explore the extent of this complicity in the context of Internet-based initiatives that set out to challenge mainstream conceptualizations of migrants and champion their cause; and in so doing it attempts to "make visible what is invisible only because it's too much on the surface of things" (Foucault, $1989 / 1996$, p. 58). More specifically, it draws on corpora compiled by the Genealogies of Knowledge project to examine the patterning of refugee/s and migrant/s and the extent to which this patterning reproduces or undermines mainstream discourses. It further examines the patterning of exiles and refugees in a corpus of modern English (re)translations of and commentaries on ancient Greek texts to demonstrate the viability of adopting a different conceptualization of refugees and other outsiders to the polity and the possibility of envisaging a different language with which to accord migrants the dignity they deserve as human subjects.

The approach adopted in the current study is informed by the work of Michel Foucault on discourse and power. In the Archeology of Knowledge, Foucault argues that although "discourses are composed of signs ... what they do is more than use these signs to designate things. It is this more that renders them irreducible to the language (langue) and to speech. It is this "more" that we must describe and reveal" (1972/2002, p. 54; emphasis in original). This "more" is a question of the complex relationship between discourse, truth, knowledge and power. Conceptualizing truth as "a thing of this world" (1980, p. 131) rather than an absolute value, Foucault explains that every society has its own regime of truth, "its "general politics" of truth" that determine "the types of discourse, which it accepts and makes function as true", as well as how discourses are sanctioned, accorded value in terms of being (un)truthful, and who may be allowed to or entrusted with deciding what is or is not true (1980, p. 131). The circulation of discourses in any society is therefore constrained by that society's regime of truth, and by the fact that discourses are "produced and transmitted under the control, dominant if not exclusive, of a few great political and economic apparatuses (university, army, writing, media)" (1980, pp. 131-132; emphasis added). This is a key element in Foucault's approach to discourse, which informs the assumption, adopted in this study, that despite the dominance and contagion of discourses produced by powerful institutions such as the political establishment and the mainstream media, there is always the possibility of elaborating alternative discourses to challenge the current regime of truth. Foucault speaks of multiple sites of power and stresses that the exercise of power extends beyond the State and its various apparatuses, which makes it possible to envision sites and modes of resistance even to the most dominant of discourses. For Foucault, who dismisses the humanist dream "of a time when knowledge will cease to depend on power" and argues instead that just as power cannot be exercised without knowledge, "it is impossible for knowledge not to engender power" (1980, p. 52), discourse is ultimately entangled with the exercise of power, with dominant regimes of truth, and with the circulation of knowledge. Those who are not satisfied with the current regime of truth relating to issues such as migration, leftwing activists among them, therefore need to elaborate and circulate alternative forms of knowledge rather than uncritically recycle and hence give legitimacy to the knowledge and discourses produced by powerful institutions.

Foucault adopted an interesting approach to the ancient world, which is particularly relevant to the current study. On the one hand, he believed that ideas cannot and should not be traced to an origin, that "[d]iscourse must not be referred to the distant presence of the origin, but treated as and when it occurs" (1972/ 2002, p. 25) and, importantly, that "there is no exemplary value for a period, which is not our period" $(1984$, p. 347). On the other hand, he argued that we can use the past to establish that a connection or a pattern that might be presented, within our current regime of truth, as self evident is not indisputable, "not linked to human nature, or to any anthropological necessity" (1984, p. 347), and hence can be challenged, rethought, and reenvisioned in new terms. In looking for alternative discursive models for conceptualizing the migrant in ancient Greek texts, this article likewise does not set out to present Greek society as exemplary in relation to the present but merely to demonstrate that our contemporary discourse on migration is governed by relations of power and a regime of truth that can and-I would argue - should be remodeled along more humane principles.

\section{Data and methods}

The data for the study comes primarily from a subcorpus of articles published by left-wing outlets, which constitute part of the Genealogies of Knowledge Internet Corpus. A secondary set of data consists of a subset of the GoK Modern English corpus: these are (re)translations of and commentaries on ancient Greek texts that are rich in references to outsiders to the polity, especially exiles and refugees. For ease of reference, I will refer to the primary set of data as the Internet Corpus and to the secondary set as the Greek-English Corpus.

The Internet Corpus totals 2,834,468 tokens and consists of articles that vary in length from 214 to 14,023 tokens, but the vast majority are between 1000 and 2500 tokens. They are drawn from 15 sources: Activist Post, Discover Society, Impolitikal, Information Clearing House, Left Flank, Left Foot Forward, Libcom.org, Mother Jones, New Left Project, Open Democracy, ROAR Magazine, Salvage Zone, The Nation, UK Indymedia and Viewpoint Magazine. Some of these, like ROAR Magazine and Salvage Zone, explicitly adopt a more radical left agenda than others like The Nation and Open Democracy. The Greek-English Corpus consists of 73 books, totaling 6,966,050 tokens (Supplementary Appendix 1). These vary in length from 2857 tokens (James Rice's 1894 translation of Isocrates' Panegyricus) to 307,343 tokens (George Campbell Macaulay's 1890 translation of The History of Herodotus). Most are translations or retranslations of ancient Greek texts, with a smaller number of commentaries, mostly by George Grote.

The first step of the analysis involves generating frequency lists for both corpora. In most corpus-based studies, the analyst begins by deciding on a cutoff point for selecting items from a frequency list (as in Jones, this volume) and then identifying those that are relevant to the topic within the reduced list. This study follows a more laborious but in my view important route, given that the primary and secondary corpora originate in very different historical and cultural locations, raising difficulties in terms of predicting beforehand what items might be key in each corpus within a broad semantic field. The full lists of both corpora were examined to identify items that could not have all been anticipated in advance, and to capture them, however infrequent, 
Table 1 Reduced frequency lists for the Greek-English and Internet Corpora: outsiders to the polity.

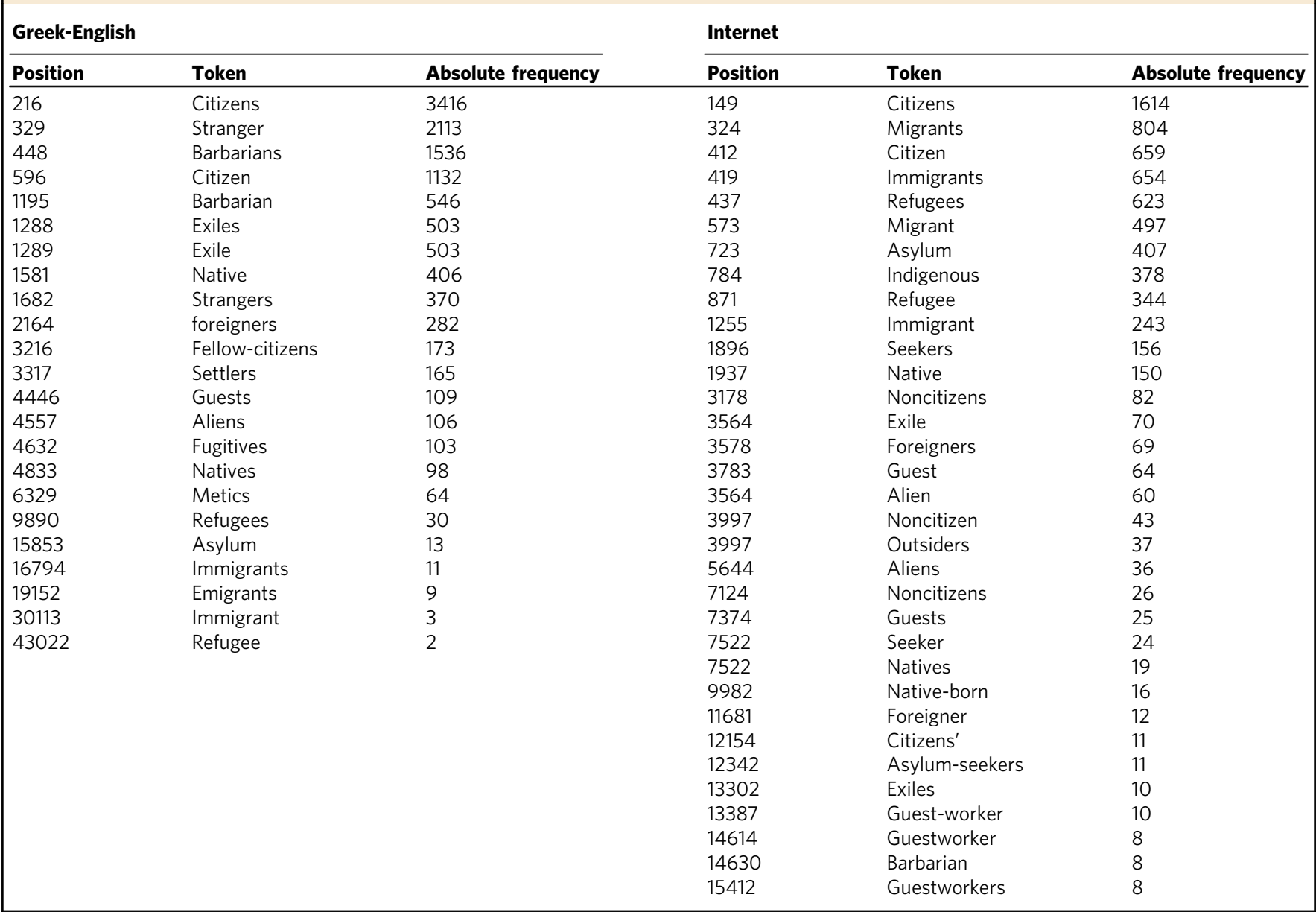

without taking either corpus as a reference point. This proved very productive. In addition to items referring to people who could be conceptualized as outsiders to the polity (such as refugee/ $s$ and foreigner/s in both corpora), the process also revealed other patterns of vocabulary that has become part of the conceptual field of talking about such people in contemporary discourses. For example, it drew my attention to items such as (un)documented, stateless, passport, visa, proof-of-citizenship, noncitizen, and citizenship-stripping in the Internet Corpus, most of which I would not have anticipated beforehand. It further alerted me to items that occur with very high frequency in the Internet Corpus but very rarely or not at all in the Greek-English corpus, such as indigenous and solidarity/ies; items that occur with much higher frequency in the Greek-English Corpus (exile/s, barbarian/s); and some-such as metics - which only feature in the Greek-English Corpus (Table 1). Finally, working with the full frequency lists as a starting point revealed interesting patterns such as the very close connection between mass and migration, which are used with very similar frequency in the Internet Corpus (383 and 394 tokens, respectively). Examining frequency lists can thus reveal strong patterns even before closer analysis is conducted using the concordance browser and the various tools developed by the Genealogies team, and despite the fact that most of these patterns cannot be examined closely in the current study because of time and space limitations. At any rate, the observations offered here do not exhaust the range of initial interpretations that are generated by the frequency list, but they suffice to demonstrate some of the ways in which it can direct our gaze towards particular lines of investigation.

\section{Table 2 Core items relevant to migrants in the Greek-English} and Internet Corpora.

\begin{tabular}{|c|c|c|c|c|c|}
\hline \multicolumn{3}{|c|}{ Greek-English } & \multicolumn{3}{|l|}{ Internet } \\
\hline Position & Token & $\begin{array}{l}\text { Absolute } \\
\text { frequency }\end{array}$ & Position & Token & $\begin{array}{l}\text { Absolute } \\
\text { frequency }\end{array}$ \\
\hline 1288 & Exiles & 503 & 324 & Migrants & 804 \\
\hline 1289 & Exile & 503 & 419 & Immigrants & 654 \\
\hline 9890 & Refugees & 30 & 437 & Refugees & 623 \\
\hline 15853 & Asylum & 13 & 573 & Migrant & 497 \\
\hline 16794 & Immigrants & 11 & 723 & Asylum & 407 \\
\hline 19152 & Emigrants & 9 & 871 & Refugee & 344 \\
\hline \multirow[t]{6}{*}{43022} & Refugee & 2 & 1255 & Immigrant & 243 \\
\hline & & & 1896 & Seekers & 156 \\
\hline & & & 3564 & Exile & 70 \\
\hline & & & 7522 & Seeker & 24 \\
\hline & & & 12342 & $\begin{array}{l}\text { Asylum- } \\
\text { seekers }\end{array}$ & 11 \\
\hline & & & 13302 & Exiles & 10 \\
\hline
\end{tabular}

Returning to the core vocabulary of interest in the current study, the items of direct relevance in the Greek-English and Internet corpora are shown in Table 2. This reduced list was again arrived at manually, by selecting items that fall within the semantic field of what might be termed "outsiders to the polity", and that occur with high frequency in one or the other corpus. In arriving at the list in Table 2, I further took into consideration both singular and plural forms of a lexical item (as in exile and 
exiles, refugee and refugees), as well as unavoidable peculiarities of the software, which treats asylum, seeker, seekers, and asylumseekers as four separate items, for instance.

For the primary set of data (Internet Corpus), the top two items of interest are migrant/s and refugee/s. These, in addition to immigrants and asylum seekers (not examined in the analysis that follows, given limitations on space), are also the tokens that intuitively present themselves as most central to the current discourse on migration. For the Greek-English corpus, the most salient items appear to be exiles/exile and refugees; these are examined in section "Refugees and exiles in the Greek-English corpus", against the backdrop of patterns identified in the Internet Corpus. The analysis makes use of various software tools developed by the Genealogies of Knowledge team. These tools build on the core modnlp architecture, which provides general text processing, Natural Language Processing (NLP), server, and user interface capabilities that other, more specialized/advanced tools can build on, as demonstrated in the analysis. See Luz (2011) and Luz and Shehaan (this volume) for further details.

\section{The Internet Corpus: caught in institutional rhetoric}

Refugee crisis, migrant workers. The first pattern of note in relation to the use of refugee/s in the Internet Corpus concerns the significant collocation of refugee with crisis, as revealed by a Mosaic representation ${ }^{2}$ of the 349 lines rendered by a search for refugee in the corpus (Fig. 1). As Krzyżanowski et al. (2018, pp. 2-3) argue, "Refugee Crisis" is an "ideologically charged" term and "is both stigmatizing" and has "an unnecessarily alarmistic connotation".

Selecting crisis in the Mosaic output highlights the lines that feature this collocate in the full concordance, irrespective of their position in relation to the keyword, and a "Delete line" function allows the analyst to condense the concordance to these specific lines (a total of 61 out of the initial 349 lines returned for refugee) by removing those that do not feature the collocation, thus facilitating closer examination of the pattern under study.

Most uses of refugee crisis in the Internet Corpus are uncritical: the authors seem to take the designation for granted and proceed to build an argument around it, as in the following examples.

Speaking in the midst of the refugee crisis, and in a country that had refused to accept any refugees from the Middle

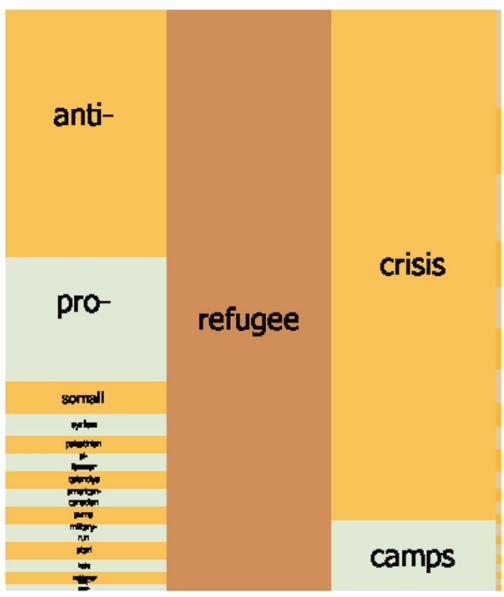

Fig. 1 Mosaic visualization of refugee in the Internet Corpus (349 lines). Collocation Strength: Local, MI3 (EXP Scale). The height of each tile is proportional to the MI3 score for the relevant collocation-here showing that crisis is the most significant collocate of refugee.
East, Trump explicitly articulated the major preoccupations of the modern far right.

Source: "POWER'S PARANOIA: THE IDENTITY POLITICS OF TRUMPISM, AT HOME AND ABROAD”, by David Wearing, Discover Society, 2018

... an easy half-hour commute now became an exercise in inconvenience. On some days, the process could add an extra hour to the journey. This is the story of a dream's implosion-and the turbulent politics behind that implosion-as Europe failed to come up with a common, continent-wide response to the refugee crisis of the past few years, and as individual countries were left to navigate these waters as best they could.

Source: "If Sweden and Denmark Are So Progressive, Why Did They Close Their Doors to Refugees?", by Sasha Abramsky, The Nation, 2016

... the United Nations has failed in its duties to keep world peace. In addition, it has failed to contain advancing international terrorism as a result of America's so-called "war on terror", nuclear proliferation, the rise of human trafficking and slavery, the fall-out from the Cold War, a mass refugee crisis that is destabilizing the European Union and atrocities such as Darfur and Rwanda, the latter of which, saw close to one million Rwandans killed in a genocide, amounting to twenty percent of the population, all whilst the UN watched and did nothing.

Source: "What Good is the United Nations, International Law, and its Courts?", by Graham Vanbergen, Activist Post, 2016

... small team of workers who sit or stand around a table cutting cables or assembling parts is that you have plenty of opportunity to shoot the breeze about a wide range of topics. While we were working in our dingy workshop, the world around us was changing rapidly: war in Syria, refugee crisis, Brexit referendum, terrorist attacks, signs of decay of the establishment.

Source: "Migration and National Social Democracy in Britain", by Angry Workers of the World, Libcom.org, 2018

One of the uncritical instances comes from one of the most radical outlets in the corpus, ROAR Magazine, and indirectly suggests why the left is not more alert to the importance of challenging the mainstream at the level of discourse: it is too focused on organizational matters, on how to run assemblies and avoid reproducing hierarchies in everyday practices, as I have argued elsewhere (Baker, 2016).

In many respects, we will have to free ourselves from capitalist time and set our own political pace. Unfortunately, however, there are some things that simply cannot wait. Pressing concerns like climate change and the refugee crisis compel us to act now, simply to save human lives and the planetary life-support systems on which they depend. This is another reason why a dynamic and versatile left capable of rising to the challenges of our times will need to rest on a broad ecology of organizational forms-each with their own strengths and weaknesses, and each operating according their own particular temporalities.

Source: “Towards a New Anti-Capitalist Politics", by Jerome Roos, Editor of ROAR Magazine, 2015 


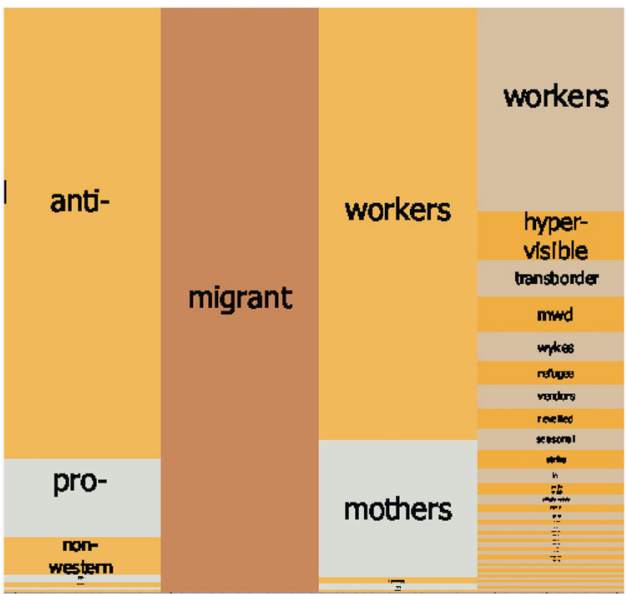

Fig. 2 Mosaic visualization of migrant in the Internet Corpus (523 lines). Collocation Strength: Local, MI3 (EXP Scale). The height of tiles shows workers to be the most significant collocate in position R1 and a significant collocate in position R2.

It is curious that a label such as refugee crisis is being taken for granted by radical left-wing activists when others have readily questioned it in less radical venues. Kansteiner, for instance, argues in a recent scholarly publication that the choice of term reflects politicians' need to "always manage the most recent migration crisis-or what they and their voters remember as the most recent crisis" (2018, p. 141). Given that the "estimated 2.2 million people [who] arrived in the territory of the European Union during the so-called refugee crisis in 2015 and 2016" only represent " $1.7 \%$ of the 130.9 million people forcefully displaced worldwide in those 2 years", and that the "511 million people" residing in the EU in 2016 "accumulated a combined GDP of $\$ 16.4$ trillion representing 21\% of global GDP", he points out, accommodating and caring for the two million refugees "hardly constitutes a serious financial or material challenge" (2018, p. 141).

Very few instances of critical use of the term that reveal some awareness of the implications of discursive practices can be found in the corpus, and these mainly involve the use of scare quotes and other distancing devices, as in the following examples.

A narrative that leaves the structural racism of Europe intact, while justifying the bombing of Syria and legitimating the continuing mass surveillance of Muslims in Europe. This focus on post-revolutionary "democratic transition", "Islamist threats" and a "refugee crisis" fails to acknowledge that the conditions that drove the revolutions did not board the private planes that Ben Ali and his fellow dictates flew into exile.

Source: "FOCUS: NARRATING THE "ARAB SPRING", FIVE YEARS ON", by Kathryn Medien, Discover Society, 2016

Starving, exhausted, bombed and mourning, Syrians still pledge fidelity to their revolution. If you seek hope-or whatever might replace hope-for the future, look to Syria first, not last. An understanding of Syria is also vital given the central place the country occupies in the so-called "refugee crisis"-or, as it might be better known, Europe's border war.

Source: “Salvage Perspectives \#3: Or What's a Hell For?", by the Editors of Salvage Zone, 2016
I return to the limitations of falling back on such textual strategies to signal critical distance at the end of this section. In the meantime, it is important to bear in mind that "[ $t]$ he framing of migration management as a "crisis" has been used to justify extraordinary and exceptional measures, which can be characterized as rapid, informal and flexible policy instruments at odds with the rule of law and the fundamental rights of refugees and other migrants" (Baldwin-Edwards et al., 2018, p. 11). It is not unreasonable to expect the radical left to avoid contributing to this type of framing by enforcing it through repeated use, with or without scare quotes.

Turning to migrant, the corpus suggests that unlike refugees, whose arrival on our territories is said to present us with a crisisboth moral and logistical, given that we have an obligation to accommodate them-migrants present us with an economic challenge. A search on migrant returns 523 instances (only six of which feature the collocation migrant crisis), with workers being the strongest collocate in both positions 1 and 2 to the right (Fig. 2).

Selecting workers in the first position to the right (R1) highlights a set of concordance lines in which the collocation occurs at all positions, making it possible to capture variant collocations such as migrant contract workers, migrant construction workers, migrant domestic workers, migrant sex workers, migrant and seasonal farmworkers, migrant women workers, migrant dairy workers, and migrant household service workers. A closer look at the full concordance further reveals that there are other collocates associated with migrant that reinforce the same pattern, such as migrant labor, migrant labor contract system, migrant economies, migrant nurses, migrant street vendors, migrant remittances, migrant fishers, migrant working class, and migrant farmworkers - the latter not highlighted by the Mosaic software, which treats farmworkers as a separate lexical item. Such items often combine in the same stretch, rendering the focus on migrants as an economic challenge highly visible, as in the following example:

Although the premise of the $\mathrm{H}-2 \mathrm{~B}$ program is to supplement sectors suffering a labor shortage with migrant labor, data and media reports reveal that employers routinely circumvent mandates to seek local hires first and seek the migrant recruitment industry to exploit visa loopholes. The system has become so ingrained in the production cycle that the local workforce, advocates say, is eclipsed by waves of migrant "perma-temps."

Source: “The Two-Tier Employment System You Haven't Heard Of', by Michelle Chen, The Nation, 2016

Restricting the analysis to the occurrence of workers, worker, migrant-worker, and farmworkers in the vicinity of migrant (mostly in position 1 to the right), this pattern accounts for 143 out of the 523 instances of migrant in the corpus. Of these, the Metafacet tool ${ }^{3}$ suggests that the majority occur in The Nation, followed by Salvage Zone (Fig. 3).

The Nation, the outlet featuring the highest number of instances (67), is also by far the best established of the outlets included in the corpus-predating the rise of the Internet, unlike all the others-and the closest to playing the role of an oppositional but credible interlocutor from the perspective of policy makers and politicians.

Founded by abolitionists in 1865 , we've long believed that independent journalism has the capacity to bring about a more democratic and equitable world. Our writers shift paradigms and open minds. Our deep investigative reporting launches congressional hearings, forces policy change, and shapes news cycles. (The Nation, About page) ${ }^{4}$ 


\section{Metafacet: Concordance Meta-data facet distributions}

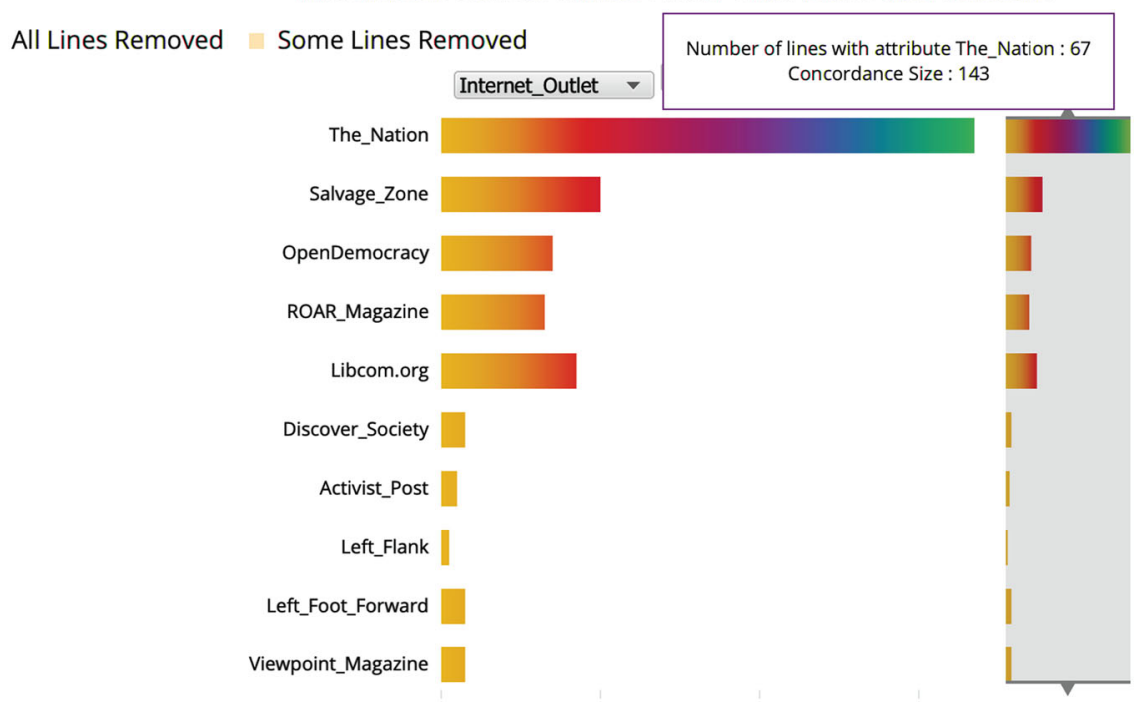

Fig. 3 Metafacet visualization for a subset of concordance lines featuring migrant workers, migrant worker, migrant-worker, or farmworkers, filtered by Internet outlet and sorted by frequency.

Salvage Zone, the next outlet on the list (with 20 instances), is one of the most radical left sources represented in the Internet Corpus and is therefore worth examining more closely. The pattern that emerges from the 20 instances featured in this outlet highlights the dilemma involved in challenging mainstream, dominant discourses, and the process of contagion that I quoted Page acknowledging at the beginning of this article. While the emphasis on the economic aspect of migrants' lives is problematic and inevitably legitimizes the distinction between political refugees and economic migrants enforced and upheld by the mainstream media and institutions, even highly radical outlets like Salvage Zone cannot challenge the reality they are attempting to intervene in by completely reconfiguring the discursive space within which they can do so and remain intelligible. All 20 instances in Salvage Zone demonstrate a clear commitment to championing the rights of migrants, who are already being discriminated against specifically in the economic sphere. What is different here, and true to Salvage Zone's mission as outlined on its About page, is the focus on challenging the discourses not only of the mainstream institutions but also, and especially, those of other socialists:

Salvage is a quarterly of revolutionary arts and letters. Salvage is edited and written by and for the desolated Left, by and for those committed to radical change, sick of capitalism and its sadisms, and sick too of the Left's bad faith and bullshit. (About page $)^{5}$

The following are some examples of this type of discourse, which challenges the left just as vehemently as it does the mainstream, and which seems to be specific to Salvage Zone:

A $\operatorname{dim}$ echo of this logic now unfolds in the amateur dramatics of social media, wherein "posh" leftists who incline toward Brexit are belabored for their supposed indifference to the fate of migrant workers. As if, by availing themselves of a moralizing idiom, the "left Bremainers" could elide the difficulties in their own position ...

Source: "Neither Westminster Nor Brussels", by The Editors, 2016
Unlike the right they do not complain of foreign languages spoken on public transport, but they hope to stem the flow of immigrant labor undercutting wages. There have been calls too to institute a closed shop exclusively for migrant workers, which would mean socialists demanding vastly increased state snooping and control over some workers on the basis of their national origin while ushering in employment discrimination through the back door by making migrant workers the most expensive to hire.

Source: "Socialism for Jingoes", by Barnaby Raine, 2017

for liberals to make radical-sounding noises-patting themselves on the back for promoting a wider-range voices, being "intersectional" about their hiring practices or including diverse models and actresses in their adverts and films-while ignoring the more pressing issues such as the status of migrant workers, wages and working conditions, racist immigration and border laws, exploitation and myriad other issues, let alone the need for systemic and drastic economic change. All-though Nair grants there are important exceptions-can be swept under the rug of liberal "intersectionality".

Source: "The Political Is Political: In Conversation with Yasmin Nair", interview by Rosie Warren, 2016

the feminism of the Angelina Jolies and the Sheryl Sandbergs of this world, so champions the rescue industry; that statistics-fabricating, lie-telling machine that conflates voluntary sex work with sex trafficking. If the corporate feminists would liberate women, why not start with the undocumented migrant workers of America? Why not start with those suffering appalling conditions legally, without the right to change employer, under the tied visa system in the UK? They will not, because they still want the marginalized and controlled cleaning their boardrooms, plucking their chickens ...

Source: "Marxism for Whores", by Magpie Corvid, 2015 


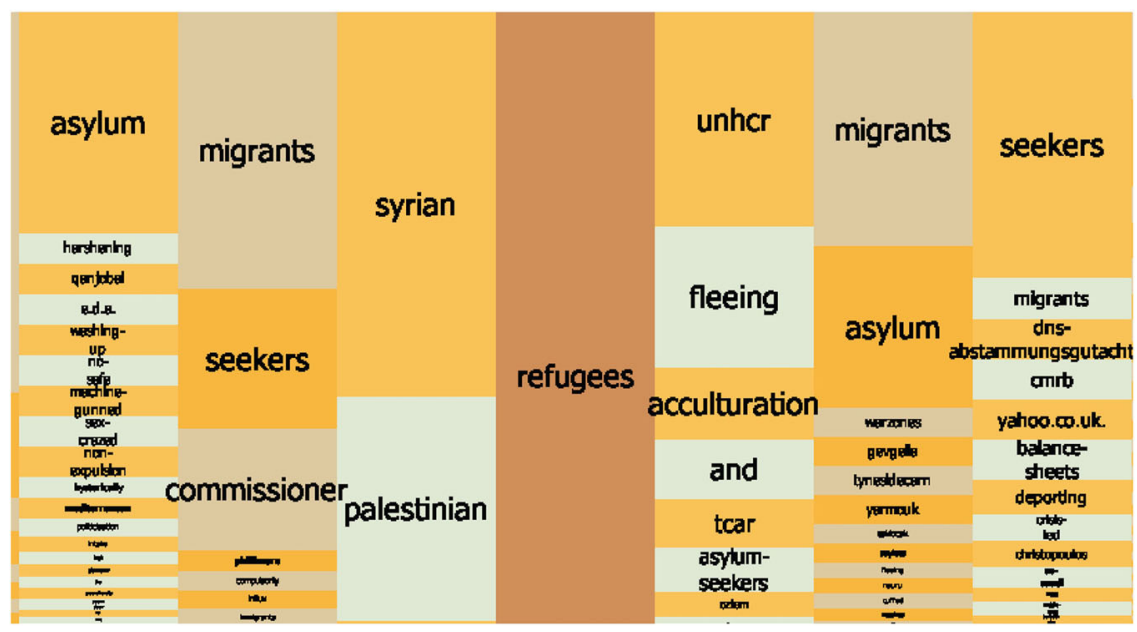

Fig. 4 Mosaic visualization for refugees (635 lines) in the Internet Corpus, Collocation Strength Local, MI3 (EXP Scale). The height of titles shows unhcr and fleeing to be the most significant collocates in position R1.

Overall, then, and bearing in mind the tension between challenging and reinforcing dominant discourses highlighted especially in the examples from Salvage Zone, the distinction between political refugees and economic migrants seems to be reinforced by the (radical) left. Interestingly, a relatively recent study by Lawlor and Tolley reveals a variation on this pattern unfolding in mainstream media in Canada, a country that has a tradition of not only welcoming but of encouraging immigration for reasons of economic utility. Their analysis confirms that the media distinguishes between immigrants and refugees but that unlike the discourses analyzed here, "there is a preference for migrants who are perceived to be economic contributors and who originate from a select group of countries" (2017, p. 968), that "refugees are portrayed as less deserving and less beneficial to Canada and more threatening than immigrants" (2017, p. 969), and that "Canadians generally perceive immigrants to be net economic contributors, whereas they see refugees as net beneficiaries" (2017, p. 972). Lawlor and Tolley conclude that in both constructing and reflecting public opinion, the media operates "a discursive hierarchy, with immigrants associated more frequently (and positively) with economic considerations and refugees associated more frequently (and negatively) with validity considerations" (2017, p. 985).

Fleeing refugees and undocumented migrants. People trying to reach Europe, Whitham (2017) argues, "have been represented in our public debate by a binary discourse, according to which each is either a "refugee", fleeing conflict, or a "migrant", traveling through choice, for "economic" reasons". Collocations involving the singular forms of these nouns-such as migrant worker/s, discussed above-confirm Whitham's observation, though in the discourse of the (radical) left rather than in mainstream public debate. The distinction between persecuted refugees forced to leave their homes, hence ultimately confronting us with an ethical dilemma, and economic migrants who leave their countries by choice in search of higher wages and better living standards is seen at play not only in the examples discussed earlier but also in instances of explicit categorization involving the plural forms of the two items:

As a traveler or resident, once you were in, you were in. And until you left, you didn't have to show your passport. Yet in early January 2016, in the face of an unprecedented flow of economic migrants, political refugees, and asylum seekers from the Middle East, North Africa, and Asia, the
Social Democratic government of Sweden unilaterally, and with almost no notice, imposed border controls over the Øresund Bridge.

Source: "If Sweden and Denmark Are So Progressive, Why Did They Close Their Doors to Refugees?", by Sasha Abramsky, The Nation, 2016.

... all countries could improve their disclosure and reporting methods with respect to labor trafficking, not just on the supply side (which too often conflates refugees and asylum seekers with "economic migrants"), but on the demand side as well.

Source: "The wastefulness of human trafficking awareness campaigns", by Dina Haynes, Open Democracy, 2017

Examining instances of refugees and migrants thus reveals complementary patterns in the Internet Corpus and reinforces the impression that the (radical) left tends to recycle many of the discursive patterns characteristic of the conceptualization of refugees and migrants by the mainstream media, the latter well documented in studies such as those by Baker (2006, pp. 73-86).

The Mosaic visualizations for refugees and migrants reveal other lexical means by which the distinction between the two is maintained and reinforced. Refugees are largely depicted as fleeing (position 1 to the right), presumably from conflict, war, persecution and other types of adversity that are beyond their control (Fig. 4). This pattern is reinforced by another strong collocation in the same position (1 to the right): unhcr, an organization whose "primary purpose is to safeguard the rights and well-being of people who have been forced to flee" (UNHCR website, "Who We Help", 6 emphasis added).

The pattern continues with the close association established between refugees and asylum seekers. As a compound that is sometimes hyphenated but mostly not, asylum seekers is treated by the software as two separate items (with asylumseekers as a third), which impacts the calculation underlying its presentation in the Mosaic tool. ${ }^{7}$ Bearing this in mind, it is clear that asylum seekers/asylum-seekers is a very significant collocate of refugees in several positions to both the left and right of this keyword, and is therefore worthy of closer examination. Selecting asylum in position 2 to the right further highlights a clear pattern of association between refugees and asylum seekers (Fig. 5). 


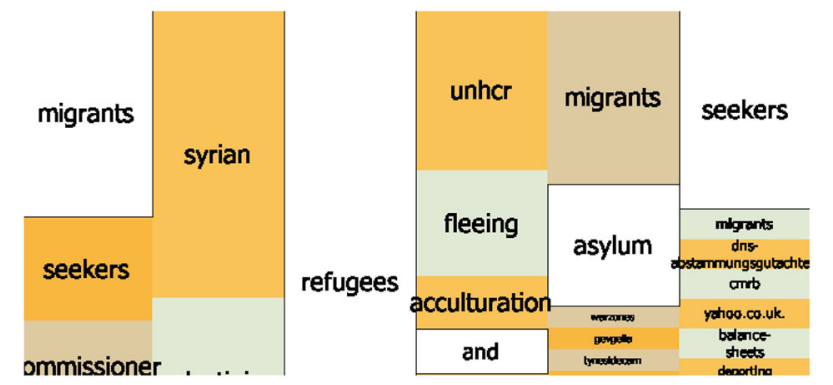

Fig. 5 Mosaic visualization of refugees in the Internet Corpus, Collocation Strength Local, MI3 (EXP Scale). Selecting asylum (R2) automatically coselects and (R1) and seekers (R3) as a single, continuous unit: refugees and asylum seekers.

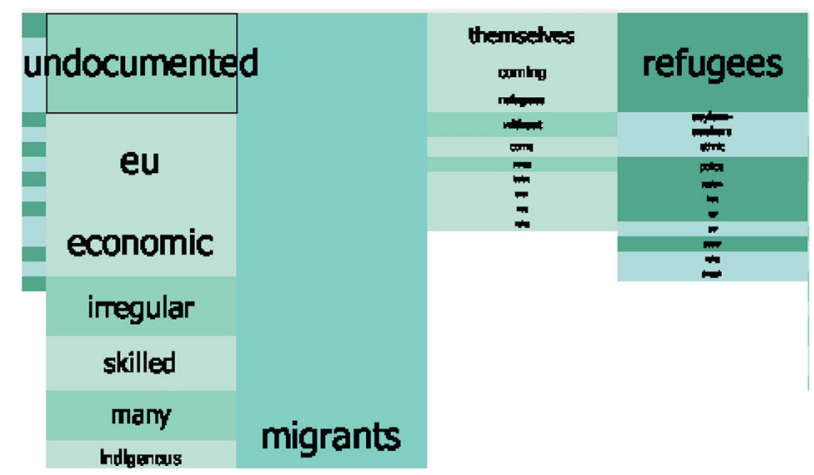

Fig. 6 Mosaic visualization for migrants in the Internet Corpus, Column frequency (no stopwords), showing economic, undocumented, and irregular as frequent collocates in position L1.

The Mosaic visualization for migrants (828 occurrences) tells a different story. Unlike fleeing refugees who (together with asylum seekers) confront us with an ethical dilemma, migrants confront us with an economic and legal challenge. Opting for a Mosaic view that prioritizes raw frequency (Column Frequency No Stopwords) ${ }^{8}$ shows economic to be a strong collocate of migrants, as expected, in position 1 to the left (Fig. 6).

A different Mosaic view, which prioritizes unexpectedness rather than raw frequency, ${ }^{9}$ reveals a more interesting pattern (Fig. 7), already evident to some extent in Fig. 6. Migrants do not only pose an economic problem, they also pose a legal problem, a problem of law and order.

Migrants are mostly undocumented (20 occurrences), illegal (5 occurrences), illegalized (a lexical item I return to shortly; 6 occurrences), irregular (12 occurrences), and these terms tend to co-occur, accompanied by other legal terminology not revealed by the Mosaic display, with the effect of positioning migrants within a detached legal discourse, as in the following examples:

Unfortunately, one of the leading candidates is a provocateur, bent upon repudiating the human rights of minority groups. The candidate has targeted, among others, the U.S. born children of undocumented and out-of-status migrants (here after "irregular" migrants), whose right to U.S. citizenship he promises to end once elected (1). While it is uncertain whether he would revoke the citizenship of the U.S. born children of irregular migrants who have been here for many years, he has made it clear that all newly born ...
Source: "IN SUPPORT OF BIRTHRIGHT CITIZENSHIP”, by Michael S. Devine, Discover Society, 2016

Pathways to permanent residency, or the Sans-Papiers ("without papers") movement in Europe, which has lobbied for the labor and human rights of asylum seekers and undocumented migrants. These kinds of movements, however, have been slow to emerge in Australia. This may be because, unlike "paperless" migrants in the EU or US, who have mobilized under the political identity of "undocumented", different categories of legal noncitizen in Australia often have little common ground politically.

\section{Source: "NONCITIZENS DOWN UNDER: HOW MIGRANT BELONGING IS CHANGING IN A NATION OF IMMIGRANTS", by Shanthi Robertson, Discover Society, 2016}

Despite the generous use of scare quotes in these examples, Kansteiner's (2018, p. 157) argument that the "exploration of minority communities from the vantage point of law enforcement ... creates a seemingly compelling causal link between migration and crime" and configures migrants as inevitably illegal still holds. This link is interestingly acknowledged by one particularly critical article in the corpus that shows awareness of the impact of discursive choices:

The unequal politics of citizenship, which is institutionalized in immigration law, produces migrant "illegality". The Border Spectacle systematically re-renders that same "illegality" into a quasi-inherent deficiency of the migrants themselves. This displacement of juridical inequalities and border injustices onto the illegalized migrants themselves -including patronizing discourses that present migrants as purely passive "victims"-inevitably contributes to the migrants' racialisation.

... the state's "protection" is benevolently extended beyond its "rightful" citizens to include some migrants, particularly women purportedly rescued from the intrinsic criminal excesses of "illegal" migration itself. The "trafficking" discourse thus narrowly identifies the source of the migrants' "exploitation" as a "foreign" one- "smugglers", and the whole "opportunistic" infrastructure of "illegal" migration itself. In this way, illegalized migrants are deemed to be in need of "protection"-from one another!

Source (for both extracts): "The border spectacle of migrant "victimization", by Nicholas de Genova, Open Democracy, 2015

Origins and numbers of refugees and migrants. Legal classifications of the type observed above are dehumanizing, because they attribute to a given person or group a status that is fixed and that is never attributed to those considered part of the polity. In the case of the term illegal, for instance, Hoops and Braitman (2019, p. 151) point out that describing a person or a grouprather than a particular act they committed-as illegal is a discursive move reserved for those positioned outside the polity: "even individuals who have committed violent acts such as murder and rape" are never referred to as "illegal citizens", nor are those caught driving under the influence described as "illegal drivers". This confirms that the designation ultimately "indicts a person's entire existence, rather than an action” (2019, p. 151).

The process of dehumanization does not end with such legal designations, however. In the case of refugees, it is complemented 


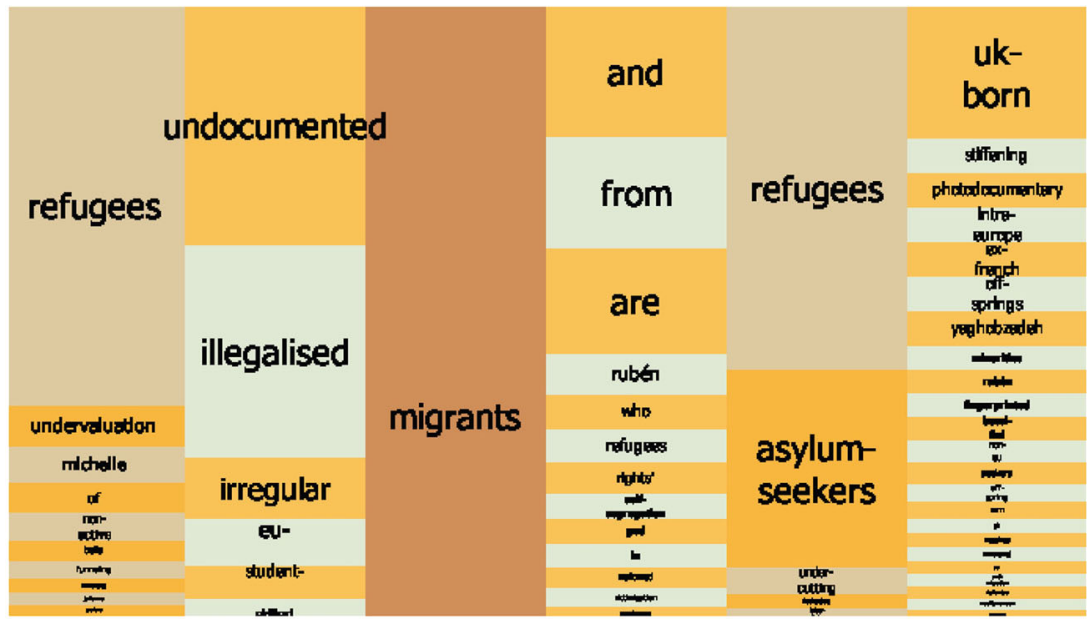

Fig. 7 Mosaic visualization for migrants (828 lines), Collocation Strength Local, MI3 (EXP Scale), showing undocumented, irregular, and illegalized as significant colloates in position L1.

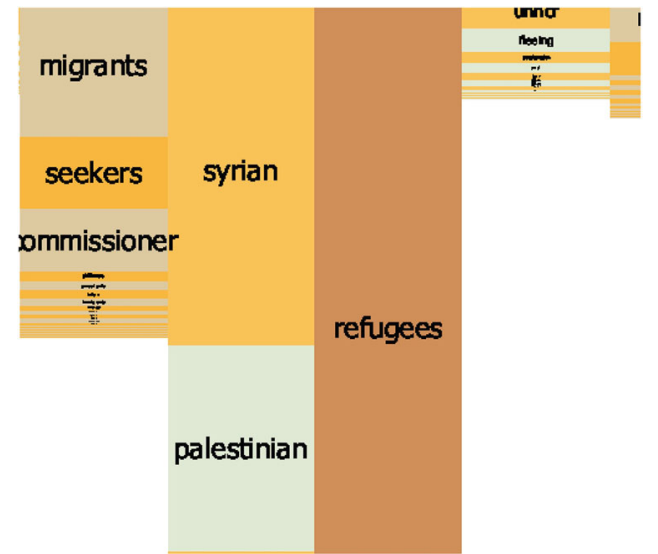

Fig. 8 Mosaic visualization for refugees (635 lines), Internet Corpus, Collocation Strength Global MI3 (EXP scale), showing Syrian to be the most significant collocate in position L1, followed by Palestinian.

by another pattern, which displays a marked emphasis on the origin of refugees: where they come from, their nationality/ ethnicity-and often their religion (Fig. 8). The Mosaic display only highlights some of these patterns and obscures others, such as those seen in the following examples:

Many of the arrivals are refugees from places like Iraq, Syria, Burma, and Afghanistan.

Source: “Democrats Don't Need to Win Texas-But They Just Might, Anyway", by Tim Murphy, Mother Jones, 2017

Muslim refugees from the Balkans and Caucasus (all labeled Turks by their European persecutors) poured into Turkey and fueled communal and religious antagonism.

Source: "Cosmopolitan citizenship in the Middle East", by Sami Zubaida, Open Democracy, 2010

Classifying groups by nationality, ethnicity or religion produces ambivalent effects and can be driven by opposing agendas. On the one hand, particular groups such as Palestinians, Syrians, or Muslims can be presented as a risk to the host country and population; on the other, they can be identified in order to argue that they are at risk and hence deserve our empathy and support. Categories of this type can therefore be used to demonize or to protect, and their prevalence in the discourse under consideration here is certainly not intended to dehumanize. Nevertheless, given the interpretive context governed by what I have already suggested is the current regime of truth and dominant, public discourse on migration, these categories are largely tainted by the overall framing of groups such as Palestinians, Arabs and Muslims as a threat to security, and by their association in public and political discourse with terrorist attacks. The contagious nature of dominant discourses acknowledged earlier notwithstanding, repeated categorization of this type plays into the kind of discourses that rely on classifications such as these to suggest that some groups are more or less worthy of support, more or less likely to integrate into the reader's community, or to pose a higher risk to security, among other implications. It further undermines principles of solidarity that are key to a critical, contestatory vision of that other world that radical left-wing activists often invoke as both possible and desirable. In section "Ancient Greece and rethinking the discourse on migration", I discuss one example of a successful challenge to this discursive environment, which manages to avoid many of the prevalent patterns analyzed here.

What is even more dehumanizing than both types of classification (by legal status or by nationality, ethnicity, or religion) is that both migrants and refugees are repeatedly quantified. This is problematic on several counts. First, as Stierl et al. (2019) argue in their critique of what they refer to as "the numbers game exploited by national governments, EU institutions, and international organizations, as well as fear-mongering news media and right-wing populist political parties", the relentless circulation of numbers "plays a crucial role in the production of a "crisis" of migration and borders". Rather than accepting the often conflicting sets of figures produced by groups and organizations such as the European Border Agency Frontex, the UN or the International Organization for Migration at face value and circulating them uncritically, activists, Stierl et al. argue, should expose the politics of numbers for what it is: an important means of generating "the homogenized and aggregate representations that are decisive for erasing the individuality and political subjectivity of people on the move, as well as effacing their collective struggles and hardships". An emphasis on numbers and statistics further reinforces the pattern of reporting in mainstream media critiqued, among many others, by the Ethical Journalism Network (White, 2015, p. 22), which found that "[j]ournalists and editors ... appear to forget that behind the plentiful numbers and statistics surrounding the migrant and refugee story are 
thousands of human-interest stories" that remain invisible to readers. Interestingly, authors of the EJN report (2015, p. 41) found that the appearance in 2015 on the front pages of most British newspapers of the story of Aylan Kurdi, the 3-year-old Syrian/Kurdish child who drowned in the Mediterranean on 2 September as his family attempted to reach Europe,

[a]lmost overnight ... reframed the rhetoric from scaremongering, as described by the front page (28 August) of the Daily Mail- "Migrants: How many more can we take" - to a more humane call for aid and hospitality "A tiny victim of a human catastrophe" (3 September).

I offer a further example of prioritizing the human story of migrants from the Internet Corpus in section "Ancient Greece and rethinking the discourse on migration" below.

Secondly, numbers and statistics have been shown to be ineffective as a means of persuading the public of the positive aspects of migration, because many now "assume that the numbers are manipulated and dislike the elitism of resorting to quantitative evidence" (Davies, 2017). Research undertaken by the think tank British Future reported that people found arguments on migration based on broad benefits to the community and on values such as fairness and compassion more persuasive, with one participant in the research quoted as saying "We chose that one [argument] because it does not have any statistics in it .... This one is pure opinion-so you can trust that" (Katwala et al., 2014, p. 28).

The patterns identified in the Internet Corpus recall the findings of other corpus-based studies such as Baker and McEnery's (2005) and Baker et al.'s (2008) of the representation of refugees and asylum seekers in the British press, and Fotopoulos and Kaimaklioti's (2016) of the representation of migrants in the Greek, British and German press. Baker and McEnerey (2005, p. 202) found that refugees are commonly described in terms of where they come from and by a premodifying, often vague expression of quantification such as "tens of thousands" or "more and more refugees"; Baker et al. report that "about one in five references to refugees and asylum seekers are accompanied by quantification" (2008, p. 287); and Fotopoulos and Kaimaklioti (2016, p. 270) similarly report that the most common collocate of migrants, immigrants, refugees and asylum seekers in position 1 to the left of the keyword in their corpus was a number, highlighting the focus on quantity. Similarly in the Internet Corpus, refugees, migrants and asylum seekers are all discursively-if not intentionally-treated as statistics, and the pattern is so pervasive and so varied in lexical manifestation that it is impossible to capture through Mosaic and other visualization tools developed by the Genealogies of Knowledge project. Examples from the most radical left outlets include the following:

UK nationals are more likely to claim benefits than foreign migrants right across the board, as the Guardian reported last year (and as the graph from FullFact demonstrates): "Of the $\mathbf{2}$ million net migrants to the UK from the eight eastern European countries that joined the EU in 2004, just 13,000 people have claimed jobseeker's allowance (JSA). This figure was not disputed by No 10."

Source: "Message to David Cameron: you have no evidence the benefit system acts as a "magnetic pull"”, by Daniel Elton, Left Foot Forward, 2014

The global numbers are sobering. By 2015, almost 244 million people lived outside of their country of birth: There were $\mathbf{2 0 . 2}$ million refugees or people living in refugee-like situations; ${ }^{10}$ the number of international students worldwide had risen above 5 million; there were an estimated $\mathbf{1 5 0 . 3}$ million migrant workers and $\mathbf{5 0}$ million irregular migrants worldwide (IOM 2014).

Source: "INEQUALITY AND ASSEMBLAGES OF NONCITIZENSHIP IN AN AGE OF MIGRATION”, by Patricia Landolt, Discover Society, 2016

or asylum in 2013 increased for the third year running: there were $\mathbf{2 3 , 5 0 7}$ applications for asylum last year, up $\mathbf{8 \%}$ on 2012 and up in total by $\mathbf{3 1 \%}$ on 2010 . The Home Office anticipates that numbers will continue to rise for the next 5 years to around 25,000 and the UNHCR expects higher numbers of refugees in the world than ever before.

Source: "BLAMING THE VICTIM-TORTURE AND THE NEW POLITICS OF EXCLUSION", by Neil Serougi, Discover Society, 2014

Again, the two patterns (quantification and highlighting the national/ethnic origin of refugees and migrants) often combine, as in the following example, where both patterns are so pervasive it is difficult to highlight them typographically:

Currently around 2.37 million people from the EU work in the UK (around 8 percent of the total working population). Around a third of all EU migrants are from Poland. Since 2014 most newly arrived migrants are from Romania and Bulgaria. Since 2014 their numbers have increased from 230,000 to around 413,000 . The most common professional categories for the so-called A10 migrants (from the ten Eastern European states) are "process operative" (36 percent) or packer (19 percent).

Source: "Migration and national social democracy in Britain", by Angry Workers of the World, Libcom.org, 2018

Finally, refugees are projected in the Internet Corpus as helpless victims with no agency. ${ }^{11}$ There is much talk of desperate, helpless refugees. Things are done to them and for them (they are killed, supported, reported on, assisted, assimilated, integrated, blamed, represented, resettled), but they do not appear to do much, other than flee from war and conflict, or at best assimilate or seek protection. The danger of reducing refugees to the status of victims, as Turner argues (2016, p. 143), is that it suppresses their political subjectivity by treating them purely as forms of biological life. At the same time, research conducted by the Refugee Studies Center at the University of Oxford, for instance, has challenged prevailing representations of contemporary refugees as passive victims and demonstrated that even Palestinian refugee youths living in some of the most adverse camp conditions in Gaza, the West Bank, Syria, Lebanon and Jordan "respond to the uncertainty of their lives with a sense of agency, as well as clearly identifiable aspirations" (Chatty, 2010, p. 319). Similarly, active forms of protest and political action are reported in studies such as Lecadet's (2016, p. 188), who asserts that despite being cast by humanitarian organizations as victims, "[t]he whole political spectrum is in evidence [in refugee camps]: from the most basic gatherings of refugees to demand improvements to their living conditions, through elections-demonstrating the appropriation of the rules of institutional politics-and movements against the NGOs, the representatives of international organizations and governments". As we will see shortly, the Greek-English corpus, the focus of section "Refugees and exiles in the Greek-English corpus", destabilizes the pattern of refugees as victims evidenced 
in the Internet Corpus considerably. However, before I discuss some of the patterns emerging in this second corpus, it is important to acknowledge that the above analysis of left-wing outlets does not account for the full patterning of the Internet Corpus nor for some more critically alert engagement with the dominant vocabulary.

The Internet Corpus: challenging the mainstream. The left is not a monolith any more than the migrants themselves are, and attempts at undermining the dominant discourse on migration are evident across several outlets. I discuss some of these briefly for the light they might shed on the difficulty of striking a balance between critically aware discourse and a discourse that is intelligible and can engage wider audiences. A more sustained examination of a single, particularly powerful intervention, from Discover Society, is offered in the concluding section.

There is some awareness in the corpus of the broader implications of adopting the type of institutional discourse discussed above, but such interventions seem to be the exception rather than the norm. A good example comes from Discover Society, where the author acknowledges the importance of attributing agency to migrants and of recognizing their humanity rather than treating them as passive victims or a logistical problem.

In the turmoil, and in the high-level discussions of numbers and costs and "solutions", individuals themselves are reduced to statistics. They are administered and managed through a restrictive policy that is premised on control and that silences the voices of the migrants themselves, excluding them from the conversations that shape their lives. Migrants are not, however, passive in accepting this silencing; across Europe, migrants are self-organizing, reaching across borders to stand in solidarity with one another and with supporters

Source: "ON THE FRONTLINE: PROTESTING AS NONCITIZENS - REFUGEE PROTEST CAMPS IN EUROPE”, by Heather Johnson, Discover Society, 2016

A number of authors adopt individual creative designations and linguistic strategies such as the use of scare quotes to introduce some fissures in mainstream discourse, but this often results in a discourse that is unwieldy and alien to many readers and potential readers, as in the following examples:

... a spectacle of enforcement at "the" border, whereby migrant "illegality" is rendered spectacularly visible. The Border Spectacle sets a scene that appears to be all about "exclusion," where allegedly "unwanted" or "undesirable"-and in any case, "unqualified" or "ineligible"migrants must be stopped, kept out, and turned around.

Source: "The border spectacle of migrant "victimization"”, by Nicholas de Genova, Open Democracy, 2015.

date for being "legally here" will be Brexit Day, rather than Referendum Day-the government's initial proposal. The "legally here" proviso is, however, a line in the sand that adds to the armoury of the Home Office in producing an ever growing population of "undocumented" (or "semicompliant") migrants in the UK whose position in terms of the vital three strands of socio-legal status (residence, welfare, and work) do not line up.

Source: "NOT ONE OF YOU ANY LONGER": EU NATIONALS' BREXIT UNCERTAINTY AND
MISTRUST", by Hannah Lewis et al./three others, Discover Society, 2017

Another strategy is to disrupt the terminological landscape by introducing neologisms that undermine and unpack widespread classifications:

Migrants only become "illegal" when legislative or enforcement-based measures render particular migrations or types of migration "illegal"-or in other words, illegalize them. From this standpoint, there are not really "illegal" migrants so much as illegalized migrants. The real origins of such illegalisations are to be found in the deliberations, debates, and decisions of lawmakers.

Source: "The border spectacle of migrant "victimization"”, by Nicholas De Genova, Open Democracy, 2015

Illegalize, illegalized, and illegalisations are hapax legomena (one-offs) that only appear in the article by De Genova.

Expressions such as We are all immigrants or We are all migrants, which recall slogans such as We are all Charlie Hebdo and We are all Palestinians, are evidence of attempts to undermine the widespread classifications and patterns of quantification discussed above, but these are also problematic for reasons outlined by the authors of two different articles, both published in Salvage Zone:

We Are All Immigrants! declaim American liberals; if that means glossing over differences between the Mayflower and the slave ship, it is very far from radical politics.

Source: "Socialism for Jingoes", by Barnaby Raine, Salvage Zone, 2017

When presenting some of these thoughts to North American colleagues, I was reminded that arguing that we are all necessarily migrants is an affront to indigenous struggles, which fight for the acknowledgement of their rights versus those of their settled colonizers.

Source: "With or Without You": Naturalizing Migrants and the Never-Ending Tragedy of Liberalis", by Maia Pal, Salvage Zone, 2018

Can the contemporary space of discursive possibility be refashioned without such alienating or perfunctory discursive moves? The past, reinterpreted through the mediating lens of translators and commentators, might provide some useful clues.

\section{Refugees and exiles in the Greek-English corpus}

Before examining some of the patterns that emerge in this corpus, it is important to acknowledge that they are not directly attributable to the source authors nor necessarily reflect how ancient Greek society actually conceptualized outsiders to the polity. Our understanding of even the most recent past is always, inevitably shaped by many layers and types of mediation and subject to ongoing (re)interpretation. In the case of the Greek-English Corpus, whatever patterns the analysis highlights reflect a mix of translator interpretation of the main text and their framing of it in introductions and prefaces. In some types of study (like Jones, 2019, 2020, this volume), specifying what patterns arise from paratexts such as introductions and what arise from the translated version of the main text may be important, though as shown by Jones the patterns identified tend to hold across both textual spheres. Given that this section does not set out to examine the extent to which any given translation or commentary captures the original meaning of Greek lexical items-a quest that would be 
further complicated by the remoteness of the ancient world being interpreted, even from the perspective of specialists-there is no need to distinguish between paratext and main text. In both cases, the textual patterns discussed reflect a specific understanding of the ancient world that is articulated by the translator or commentator.

The Greek-English Corpus, moreover, is not examined here in order to identify interventions on the part of the translator or how certain concepts such as democracy, citizenship, or refugees evolved over time, but as a source of inspiration, to help us envision an alternative language with which to speak about a key topic in contemporary life. With these provisos in mind, I begin by looking at the pattering of refugee/s.

There are 30 instances of refugees and two of refugee in the corpus (a total of 32). A concordance of 32 lines is easy to inspect closely without the help of tools like Mosaic. Nevertheless, the Mosaic visualization (Fig. 9) does signal an interesting albeit mixed pattern that reflects more agency being attributed to refugees, who actively adopt, settle, escape, occupy - as well as flee.

As the Metafacet visualization (Fig. 10) reveals, the vast majority of references to refugee/s occur in Thucydides' The

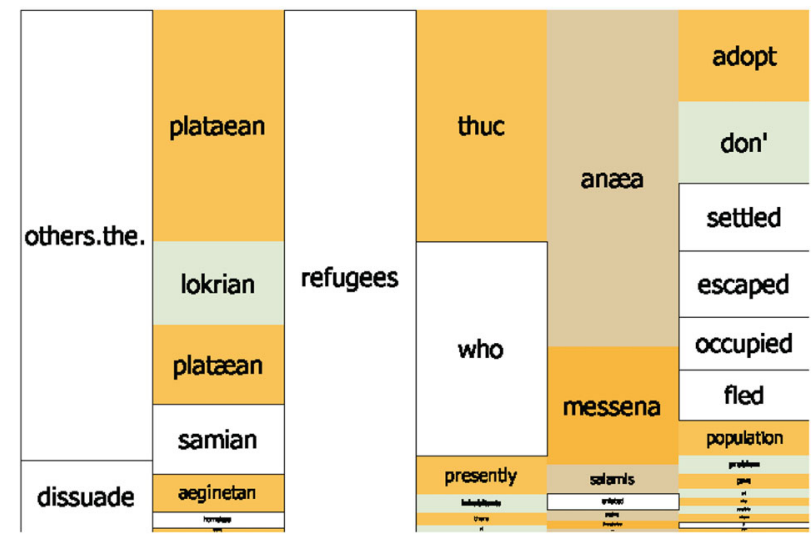

Fig. 9 Mosaic visualization for refugee/s in the Greek-English Corpus, Collocation Strength Local, MI3 (EXP scale), showing settled, escaped, occupied, and fled as significant collocates in position R3, preceded by who in position R1 (suggesting the attribution of the actions in R3 to refugees).

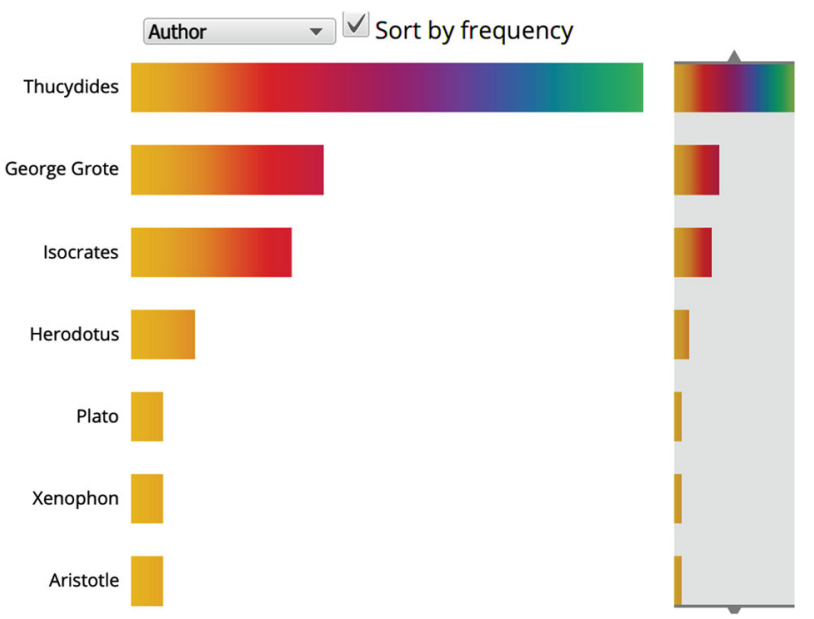

Fig. 10 Metafacet visualization for refugee/s in the Greek-English Corpus, filtered by author (all 32 occurrences).
Peloponnesian War (which exists in various translations in the corpus) and George Grote's eight-volume History of Greece ${ }^{12}$. The examples from these sources show refugees exercising their agency in a variety of ways and holding enough power for other parties to want to dissuade them from adopting or persuade them to follow particular courses of action.

His timely arrival saved the place, which Brasidas attacked the next morning, both from the river and the land, without effect: and the refugees who retired by virtue of the treaty from Amphipolis, found shelter at Eion, and contributed to its security.

Source: History of Greece, Volume 6, by George Grote, 1851

The capture took place about the time of the second invasion of Attica. The refugees who settled in Notium again quarreled among themselves.

Source: The Peloponnesian War, Thucydides, translated by Benjamin Jowett, 1881

for the Samian refugees, who had settled there, aided the Peloponnesian navy by sending them pilots; they likewise took in fugitives from Samos and kept the island in a state of perpetual alarm.

Source: The Peloponnesian War, Thucydides, translated by Benjamin Jowett, 1881

They also sent envoys to Athens immediately to provide a self-serving explanation of what had been done and to persuade refugees there not to engage in any controversial activities, so that there would not be countermeasures.

Source: The Peloponnesian War, Thucydides, translated by Steven Lattimore, 1998

This motion made, they compelled it to be adopted, and instantly sent off envoys to Athens to justify what had been done and to dissuade the refugees there from any hostile proceedings, which might lead to a reaction.

Source: The Peloponnesian War, Thucydides, translated by Richard Crawley, 1874

Of more interest is the figure of the exile, given that there are many more occurrences of exiles (503) and exile (503) in the corpus. I restrict the analysis to exiles given the abundance of examples and the fact that exile is likely to be used predominantly as a noun relating to the state of being exiled, or as a verb, to mean expelling someone from a country. The output of the concordance for exiles was further filtered, using the Metafacet tool, to restrict the analysis to the set of files that feature $>20$ instances of this item (Fig. 11), allowing me to reduce the number of concordance lines from 503 to 382 and to examine the latter closely. This filtering was necessary given the wide range of collocates relevant to the analysis I present below, none of which occurs with sufficient frequency to be captured by the Mosaic tool.

A concordance of exiles in this reduced set of data confirms the same pattern attested for refugee/s, as in the following examples:

But while they were on the march they were attacked at Coronea by the Boeotian exiles from Orchomenus, together with some Locrians and Euboean exiles and others who held the same political views, and were defeated, some of the Athenians being slain and others taken alive. 


\section{Metafacet: Concordance Meta-data facet distributions}



Fig. 11 Metafacet visualization for exiles in the Greek-English Corpus, filtered by filename and reduced to files with $>20$ occurrences.

Source: The Peloponnesian War, Thucydides, translated by Charles Foster Smith, 1919

for the prominent people were driven out by being unjustly treated at their hands, but then the exiles gathered together, came back, and overthrew the popular government.

Source: Politics, Aristotle, translated by Joe Sachs, 2012

A considerable body of exiles, however, expelled on that occasion, now invoked the aid of Pachês to reinstate them, and to expel the Arcadians.

Source: History of Greece, Volume 6, by George Grote, 1851

Exiles are not only attributed considerable agency, but are also presented as a force to be reckoned with and taken into consideration when making political decisions:

Upon hearing this the Phliasians conceived the fear that if the Lacedaemonians made an expedition against them, some of the people within the walls would let them into the city. For not only were there many kinsmen of the exiles in the city, and people who were friendly to them for other reasons, but also, as is indeed usual in most cities, some desired a change of government and therefore wanted to bring back the exiles. On account, then, of such fears, the Phliasians voted to take back the exiles ...

Source: Hellenica, Xenophon, translated by C. L. Brownson, 1918-1921

These were partly the remnant of that faction which had set-up, 7 years before, the oligarchy of Four Hundred, and still more, the exiles, including several members of the Four Hundred, who now flocked in from all quarters. Many of them had been long serving at Dekeleia, and had formed a part of the force blockading Athens. These exiles now revisited the acropolis as conquerors, ...

Source: History of Greece, Volume 8, by George Grote, 1851
These textual patterns seem to support Gray's discussion of the treatment of refugees and exiles in ancient Greek cities. Gray (2016, p. 197) talks of extensive privileges, including hereditary honorific citizenship, being granted to Akarnanian exiles, who were allies of the Athenians. The aim of such special treatment to exiled allies "was partly to provide an incentive to other Athenian allies, or potential allies, to exert themselves on Athens' behalf", but also “aid to certain exiles could serve a polis's self-interest by raising the prospect of good treatment in return, perhaps in the event that the hosts should find themselves exiled in future" (2016, p. 199). The ancient world, it seems, recognized the vulnerability of all humans, including both exiles/refugees and their hosts. Importantly, Gray acknowledges that the Athenians, much like the Europeans today it needs to be said, "had done much to create, as well as to help, refugees while running their fifthcentury BC empire" (2016, p. 200). That they favored allies in what appears to be a self-serving, instrumentalist manner does not preclude the fact that their support for these groups also had more noble aims (2016, p. 202):

The Athenian city of refuge was not seeking to be an impartial melting-pot ... the Classical Athenians approached and represented their granting of aid to particular refugees as a way of maintaining particular useful, reciprocal diplomatic relationships, but also as part of a radical project to change the world, in an egalitarian and democratic direction, in furtherance of specific historical struggles for freedom and equality. This is true even though, in practice, that project was closely bound up with Athenian interests, and even Athenian imperialism, in ways which continue to be debated vigorously.

Gray further stresses that the Athenians did not treat such groups as helpless victims; instead they "strove to equip adult male refugees with the means to continue to act, even in exile, as self-sufficient, autonomous political agents".

Protecting exiles seems to have been understood as an ethical imperative in ancient Greece, much as it is today in relation to refugees and asylum seekers, in theory if not in practice. However, importantly, the exiles themselves also had enough agency to invoke that imperative and to shame those who saw fit to 
disregard it. A particularly revealing example from the GreekEnglish corpus comes from a collection entitled Stories from Thucydides, collated and translated in 1910 by H.L. Havell.

For this senseless barbarity he was severely rebuked by a deputation of Samian exiles, now living on the mainland, who met him at Ephesus. His was a strange method, they remarked with bitter irony, of helping the Ionians to recover their liberty-to butcher defenseless men, who had done him no harm, but looked to him for rescue from their bondage to Athens!

A strikingly similar illustration from ancient Greek literature is used in the Internet Corpus in a way that suggests potential avenues for thinking beyond the current "societal discursive ecosystem" (Hoops and Braitman, 2019, p. 150) that most leftwing authors seem unable to break away from.

\section{Ancient Greece and rethinking the discourse on migration}

In one of the most powerful articles in the Internet Corpus, the author directly invokes the ancient Greek world in order to shame today's Europeans in relation to the treatment of migrants. Published in Discover Society in 2016, the article displays several layers of translation and mediation. Authored by Stefan Jonsson, it is translated from Swedish by Anna Holmwood, and quotes liberally from an English translation by E.D.A. Morshead of Aeschylus's play The Suppliants, "the oldest text we have on refugee and asylum law" according to the author/translator. The Suppliants tells the story of "a boatload of refugees" which "travels across the Mediterranean to the city of Argos. They are Danaus and his fifty daughters, who have fled Egypt to escape forced marriage to Aegyptus' 50 sons. Like today's refugees, they seek protection in temples, where they are under the patronage of the gods". Pelasgus, the King of Argos, remarks that they "resemble African women" in appearance rather than the daughters of his own country, but the women remind him that they are "of the same flesh and blood as he" and threaten to hang themselves in the temple if he sends them away.

Pelasgus faces the same dilemma that politicians and opinion leaders face today: if he allows the women in, "he might be accused of shouldering the city with an unreasonable burden to support them"; even worse, he exposes his city to hostilities from the Egyptian suitors who "would come to claim their women", thus jeopardizing the security of his people. Appealing to his people to share the burden of decision with him, Pelasgus finally delivers a powerful speech in favor of granting asylum to the women, and his people vote in favor. The author of the article uses this story to argue that today, as in ancient Greece, democracy requires a belief in human dignity, that " $[\mathrm{t}]$ he future of democracy now hangs, just as it did 2479 years ago, on how society treats those seeking shelter", and that the "right to asylum is not something we can choose to reject, unless we are also prepared to choose who we treat as humans and who we will, with a quick wave of the hand, send to their death".

This article provides a helpful model for the kind of discourse that can inspire empathy without turning the object of that empathy into a helpless victim, and that can treat those whose rights it advocates as equals. It does not downplay the dilemma posed by migration, but does not treat it as a logistical or security issue either. It shames (European) readers by urging them to reflect on their own history and the contradictions that have made Europe "deadly for anyone not white and Christian". "European history is largely the history of a violent dialectic", it reminds its reader, "[o]n the one hand, the universalism that Europeans claimed as the means by which they would save the rest of the world. On the other, the protectionism in whose name Europeans have shut their borders to save themselves from the rest of the world".

At no point does the article quantify migrants or argue for their contribution to the economy or their workers' rights. Instead, it suggests that because the migrant defies boundaries, he/she is a metaphor for both menace and promise, that European literature "records the testimonies of how each community, with varying success, handled its inevitable vulnerability-equally a possibility -that is the result of bordering an alien world". The past is offered as a mirror and a source of reflection on current dilemmas in a complex, aspirational form of discourse.

Negotiating the discursive impasse. Kansteiner (2018, p. 158) wonders: "How can we better imagine the migration experiences of the past to help solve perceived migration crises today?". I have tried to address this question by looking for textual patterns in nineteenth- and early twentieth-century texts originating in classical antiquity that reveal a different conceptualization of the migrant, and at an extended example from current radical leftwing discourse that also draws on ancient Greece as a model for rethinking our contemporary approach to migration.

A number of studies suggest that it is not unrealistic to draw on ancient Greek society for more productive models of conceptualizing the migrant, the refugee or the exile, as the author of the article in Discover Society has done. Roisman tells us that "Athenian politicians introduced into their polemics and, consequently, into our evidence what may be called the figure of the "honorable exile"” and that "Herodotos sang their praises" (1984, p. 28). "The more democratic Athens became", he continues, "the more it cultivated the heroic tradition of struggle from exile against tyranny" and the more Athenians "added dignity and honor to the experience of exile by viewing it as a service to the public" (1984, p. 30). Gray (2016, p. 203) asserts that "ancient Greece was rich in self-confident, resilient and politicized refugees" and that "Greek cities' voluntary social, economic and religious associations ... often cut across the citizen-foreigner boundary to include foreign residents, whether they were forced or voluntary migrants". This picture oversimplifies the complexity of Athenian society, but it allows us at least to imagine a different kind of language for speaking about refugees and migrants today. As Jodi Dean puts it, "[f]or the left to be able to make a break we have to speak a language that is not already the one we're in" (Dean, 2012). Ultimately, I believe, whether that language is drawn from some source in the past or invented anew, the left needs to find ways of thinking outside the current discursive box created by mainstream institutions, outside the contemporary regime of truth. And translations, as dynamic interpretations that generate their own discourses, can be a productive source to draw on.

Received: 10 September 2019; Accepted: 19 December 2019; Published online: 21 January 2020

\footnotetext{
Notes

1 Page is a senior caseworker in public law and founder of No Walls (https://www.nowalls-dl.org)

2 The Mosaic visualization (Luz and Sheehan, 2014, this volume) generates positional word statistics based on the output of the concordance browser, i.e., on the result of a search on a given lexical item such as refugee. The MI3 score is calculated by cubing the observed frequency, dividing this by its expected frequency in the corpus selected, and then taking the logarithm to the base 2 of the result. The higher the MI3-score (and, consequently, the greater the height of the word box), the stronger the significance of the collocation. For further details, consult the relevant section of the
} 
Genealogies User Manual, available at http://genealogiesofknowledge.net/software/ manual/\#mosaic.

3 The Metafacet tool allows the user to see the number of lines associated with a particular facet of the metadata, such as source language or publication date, and to filter the concordance based on the attribute selected. For further details, see the relevant section of the Genealogies User Manual, available at http:// genealogiesofknowledge.net/software/manual/\#facets.

4 https://www.thenation.com/about-us-and-contact/.

5 http://salvage.zone/about/.

6 https://www.unhcr.org/uk/who-we-help.html.

7 It is possible to run a concordance search for asylum + seeker $^{*}$ that would capture these three variations, giving us a total of 177 occurences in the Internet Corpus. A Mosaic visualization of the output can then be generated, but it would be a visualization of asylum + seeker $^{*}$ as keyword, not of refugees. The point here is that the Mosaic software treats any series of letters with a space on either side as a separate lexical item, with implications for the way it calculates frequency or significance. It is currently not programmed to amalgamate such variations-a refinement to the software that is planned for the next phase of development. (The asterisk is a wildcard that represents one or more characters in pattern matching. In this case it instructs the software to return searches not only for asylum seeker but also asylum seekers).

8 Column Frequency prioritizes raw frequency; the height of each box is directly proportional to its frequency. No Stopwords means that words that occur with a frequency above a certain threshold (essentially function words) are removed to reduce the level of noise in the visualization. See http://genealogiesofknowledge.net/ software/manual/\#mosaic.

9 That is, it highlights collocates that co-occur with significantly greater frequency than expected if chance alone were at play.

10 As one of my co-investigators on the Genealogies of Knowledge project, Saturnino Luz, explains: "These "sobering numbers" translate to $3.3 \%$ and $0.27 \%$ of the world population in 2015, far less alarming than the nominal figures suggest. In this particular use of numbers as collocates of refugees and migrants the usage might have the effect of dehumanizing, but also of accentuating an impression of crisis surrounding the phenomenon of migration" (personal communication, 4 September 2019), as I have already argued.

11 The discourse of the far right, on the other hand, tends to attribute considerable agency to refugees and migrants (as well as foreigners in general), by referring to them with terms such as invaders, thus implying that they are consciously trying to attack or undermine the Western Fort. I am grateful to Jan Buts for drawing my attention to this pattern, which would be interesting to examine in the far right sources included in the Internet Corpus.

12 Grote's History is not a translation or a commentary per se, but a work that relies very heavily on the writings of Herodotus, Thucydides and Xenophon, albeit with some critical distance.

\section{References}

Baker M (2016) The prefigurative politics of translation in place-based movements of protest: Subtitling in the Egyptian revolution. The Translator 22 (1):1-21

Baker P (2006) Using corpora in discourse analysis. Bloomsbury Academic, London \& New York, NY

Baker P, McEnery T (2005) A corpus-based approach to discourses of refugees and asylum seekers in UN and newspaper texts. J Lang Politics 4 (2):197-226

Baker P, Gabrielatos C, Khosravinik M, Krzyżanowski T, McEnery T, Wodak R (2008) A useful methodological synergy? Combining critical discourse analaysis and corpus linguistics to examine discourses of refugees and asylum seekers in the UK press. Discourse Soc 19(3):273-306

Baldwin-Edwards M, Blitz BK, Crawley H (2018) The politics of evidence-based policy in Europe's 'migration crisis'. J Ethn Migr Stud 45(12):1-17

Chatty D (2010) Palestinian refugee youth: agency and aspiration. Refugee Surv Q 28(2\&3):318-338

Davies W (2017) How statistics lost their power-and why we should fear what comes next. The Guardian, 19 January. Available at https://www.theguardian. $\mathrm{com} /$ politics/2017/jan/19/crisis-of-statistics-big-data-democracy. Accessed 10 Dec 2019

Dean J (2012) Saying 'we' again: a conversation with Jodi Dean on democracy, Occupy and communism, interviewed by Thomas Beibricher and Robin Ceilkates. Available at http://criticallegalthinking.com/2012/11/06/saying-weagain-a-conversation-with-jodi-dean-on-democracy-occupy-andcommunism/. Accessed 10 Dec 2019

Fotopoulos S, Kaimaklioti M (2016) Media discourse on the refugee crisis: On what have the Greek, German and British press focused? Eur View 15:265-279

Foucault M (1972) The archaelogy of knowledge (trans: Sheridan A M). Routledge, London \& New York, NY, 2002
Foucault M (1980) Power/knowledge: selected interviews and other writings 19721977, (ed: Gordon C) (trans: Gordon C, Marshall L, Mepham J, Soper K). Pantheon Books, New York

Foucault M (1989/1996) Foucault live (Interviews, 1961-1984), In: Lotringer S (ed) (trans: Hochroth S, Johnston J). Semiotext(e), New York

Gray B (2016) Exile, refuge and the Greek polis: Between justice and humanity. J Refugee Stud 30(2):190-214

Hoops JF, Braitman K (2019) The influence of immigration terminology on attribution and empathy. Crit Discourse Stud 16(2):149-161

Jones H (2019) Searching for statesmanship: A corpus-based analysis of a translated political discourse. Polis 36(2):216-241. Available at https://brill.com/ view/journals/agpt/36/2/article-p216_2.xml. Accessed 10 Dec 2020

Jones H (2020) Jowett's Thucydides: a corpus-based analysis of translation as political intervention. Translation Studies. (in press)

Kansteiner W (2018) Unsettling crime: memory, migration, and prime time fiction. In: Bachmann-Medick M, Kugele J (eds) Migration: Changing concepts, critical approaches. De Gruyter, Berlin \& Boston, pp. 141-166

Katwala S, Ballinger S, Rhodes M (2014) How to talk about immigration. British Future, London. Available at http://www.britishfuture.org/wp-content/ uploads/2014/11/How-To-Talk-About-Immigration-FINAL.pdf. Accessed 10 Dec 2019

Krzyźanowski M, Triandafyllidou A, Wodak R (2018) The mediatization and the politicization of the "refugee crisis" in Europe. J Immigr Refugee Stud 16 $(1-2): 1-14$

Lawlor A, Tolley E (2017) Deciding who's legitimate: News media framing of immigrants and refugees. International. J Commun 11:967-991

Lecadet C (2016) Refugee politics: self-organized 'government' and protests in the Agamé refugee camp (2005-13). J Refugee Stud 29(2):187-207

Luz S (2011) Web-based corpus software. In: Kruger A, Wallmach K, Munday J (eds) Corpus-based translation studies-research and applications. Bloomsbury Academic, London, pp. 124-149

Luz S, Sheehan S (2014) A graph based abstraction of textual concordances and two renderings for their interactive visualisation. In: Proceedings of the 2014 International Working Conference on Advanced Visual Interfaces. ACM, New York, pp. 293-296

Page P (2018) Home office phrasebook: How to speak the dialect of dehumanisation. Available at https://unlocked.org.uk/2018/12/07/your-pocket-homeoffice-phrasebook-a-dialect-of-dehumanisation/. Accessed 10 Dec 2019

Rabinow P (ed) (1984) The foucault reader. Pantheon Books, New York, NY

Roisman J (1984) The image of the political exile in archaic Greece. Anc Soc 15/ 17:23-32

Stierhl M, Heller C, De Genova N (2019) Numbers (or, the spectacle of statistics in the production of "crisis"). New keywords collective: Europe/crisis: New keywords of "the crisis" in and of "Europe". Available at http://nearfuturesonline. org/europecrisis-new-keywords-of-crisis-in-and-of-europe-part-4/. Accessed 10 Dec 2019

Turner S (2016) What is a refugee camp: Explorations of the limits and effects of the camp. J Refugee Stud 29(2):139-148

UNHCR (n.d.) Who we help. https://www.unhcr.org/uk/who-we-help.html Accessed 10 Dec 2019

White A (ed) (2015) Moving stories: International review of how media cover migration. Ethical Journalism Network, London

Whitham B (2017) On seeking asylum from poverty: Why the refugee/migrant paradigm cannot hold. MMP Guest-Authored Series, No. 1. MMP, Amman

\section{Acknowledgements}

This research was conducted as part of the Genealogies of Knowledge project, and supported by the Arts and Humanities Research Council Grant Reference AH/M010007/1

\section{Competing interest}

The author declares no competing interest.

\section{Additional information}

Supplementary information is available for this paper at https://doi.org/10.1057/s41599 019-0386-7.

Correspondence and requests for materials should be addressed to M.B.

\section{Reprints and permission information is available at http://www.nature.com/reprints}

Publisher's note Springer Nature remains neutral with regard to jurisdictional claims in published maps and institutional affiliations. 
(c) (i) Open Access This article is licensed under a Creative Commons Attribution 4.0 International License, which permits use, sharing, adaptation, distribution and reproduction in any medium or format, as long as you give appropriate credit to the original author(s) and the source, provide a link to the Creative Commons license, and indicate if changes were made. The images or other third party material in this article are included in the article's Creative Commons license, unless indicated otherwise in a credit line to the material. If material is not included in the article's Creative Commons license and your intended use is not permitted by statutory regulation or exceeds the permitted use, you will need to obtain permission directly from the copyright holder. To view a copy of this license, visit http://creativecommons.org/ licenses/by/4.0/.

(C) The Author(s) 2020 